\title{
Application of Non-destructive Testing to Evaluate the Performance of Bridges Structures
}

Diego Jesus de Souza ${ }^{1}$, Elaine Souza dos Santos ${ }^{2}$, Éric Pianizolli Flôr ${ }^{3}$, Gabriel Pereira Marinho², Giovana Costa Reus $^{4}$, Heloise Cristine Cezario ${ }^{5}$, Letícia Andrade Camara ${ }^{6}$

1. Department of Civil Engineering, University of Ottawa, Ottawa K2P 0M1, Canada

2. Department of Civil Construction, Universidade Federal do Parana, São José dos Pinhais 83040-334, Brazil

3. Department of Civil Construction, Universidade Federal do Parana, Linhares 29902-190, Brazil

4. Department of Civil Construction, Universidade Federal do Parana, Curitiba 80630-280, Brazil

5. Department of Civil Construction, Universidade Federal do Parana, Campo Largo 83604-230, Brazil

6. Department of Civil Construction, Universidade Federal do Parana, Curitiba 80060-120, Brazil

\begin{abstract}
Bridges are important elements in road system and can influence the entire economy of cities and region. Usually, these structures have high financial investments for their constructions, in this way, maintenance and conservation become so important. Inspection is a technical activity that covers several operations, including performance analysis; examination; final performance report, other operations may be necessary, such as maintenance work, recovery, strengthening and rehabilitation. Technical examination together with some test methods allows a critical and parametric judgment of the bridge performance by minimizing the subjectivity of visual evaluations, and permits a more detailed diagnosis. This paper discusses the methodology to perform tests to complement the assessment recommended by DNIT (Brazilian National Department of Transport Infrastructure), which consists only on a visual judgment. This approach provides technical basis to classify the bridges as its need and urgency of maintenance.
\end{abstract}

Key words: Non-destructive testing, bridges, concrete durability.

\section{Introduction}

Many bridges in Brazil have more than 40 years of use, and with much of their life cycle already achieved, the banning of these structures has social, environmental and economic losses. Therefore, routine inspections are a key to verifying functional and structural conditions of these structures.

Most concrete bridges in the world are evaluated by visual inspection [1]. In this context, tests for bridge inspections may reduce subjectivity improving the accuracy of results obtained in analysis. Visual inspection and registering of damages occurring in the existing assessment and currently used by DNIT (Brazilian National Department of Transport

Corresponding author: Diego Jesus de Souza, M.Sc., B.Eng., research fields: concrete durability, bridges and structures.
Infrastructure) [2], which does not give a more profound understanding of the structure's situation and its expected useful life.

The tests proposed in this study help to identify the possible deterioration mechanisms and analyze the durability of the structure [3-5].

Tests were performed in accordance with standards and the results were analyzed in comparison with values based on laboratorial means. Results obtained made it possible to compare and verify the importance of complementation provided by the tests [2].

\section{Inspection and Evaluation Methods}

Tests performed in bridges are: evaluation of the surface hardness of concrete; electrical resistivity and corrosion potential. Inspection routine will also be detailed, which proposes to evaluate the performance of bridge from visual assessment as established by the 
DNIT [2]. Tests intend to complement the methodology proposed by the department, ensuring assessments that are more technical.

\subsection{Evaluation of the Surface Hardness of Concrete}

Rebound surface hardness was used to approximately predict the compressive strength with empirical constitutive relation of concrete. For this purpose, the analysis procedure ABNT NBR 7.584 [6] was used. This method requires a clean, dry and uniform surface. It is recommended to perform at least 16 measurements in the same area of the concrete; however, measurement points must be spaced at least in $3 \mathrm{~cm}$. Fig. 1 illustrates the ideal area to analyze the surface hardness of the concrete.

After the measurement, Eq. (1) was used to define the compressive strength as recommended by the equipment maker. The equipment used was the "Hammer Concrete Test-Original Schmidt" by Proceq. The hammer pushes a spring that clashes with the tested area. The data obtained in the experiment are correlated with data obtained on extracted evidence presses:

$$
f_{c k}=2.77 e^{0.048 Q}
$$

where:

$$
\begin{aligned}
& f_{c k}=\text { compressive strength of the concrete (MPa); } \\
& Q=\text { measured value }
\end{aligned}
$$

\subsection{Electrical Resistivity}

The electrical resistivity varies with the permeability and the degree of ionization of concrete. The corrosion rate is inverse to the electrical resistivity, so this influence can be a controlling factor of the electrochemical reaction as reinforcement corrosion [4].

The measurement of resistivity is realized by electrical current passing by the concrete and read by the equipment. The equipment has four aligned electrodes. The internal ones make the potential difference reading and the electrical current is applied to the external ones. The equipment used was the
“Resipod Measurement Resistivity” also by Proceq company. Interpretation of values is indicated in Table 1.

\subsection{Corrosion Potential}

Corrosion potential is one of the most used electrochemical methods to monitor and evaluate the corrosion of reinforcement concrete. In this method, a qualitative evaluation of the corrosion process is made through maps of the structure's corrosion potential, which shows the most probable areas for the degradation process to occur [7].

It is common to perform corrosion potential measurements by using a copper electrode/copper sulfate (Fig. 2). It consists of a plastic or glass tube and its interior is formed by a copper rod immersed in a saturated aqueous solution of copper sulfate [3]. The electrode contact edge is formed by a felt-tip, thereby providing electrical continuity of the reference electrode with the working electrode-system steel/concrete.



Fig. 1 Rebound method.

Table 1 Intervals to interpretation of resistivity measurements.

\begin{tabular}{ll}
\hline Resistivity $(\Omega \cdot \mathrm{cm})$ & Risk of steel bar corrosion \\
\hline$<5,000$ & Very high \\
5,000 to 10,000 & High \\
10,000 to 20,000 & Moderate \\
$>20,000$ & Low \\
\hline
\end{tabular}




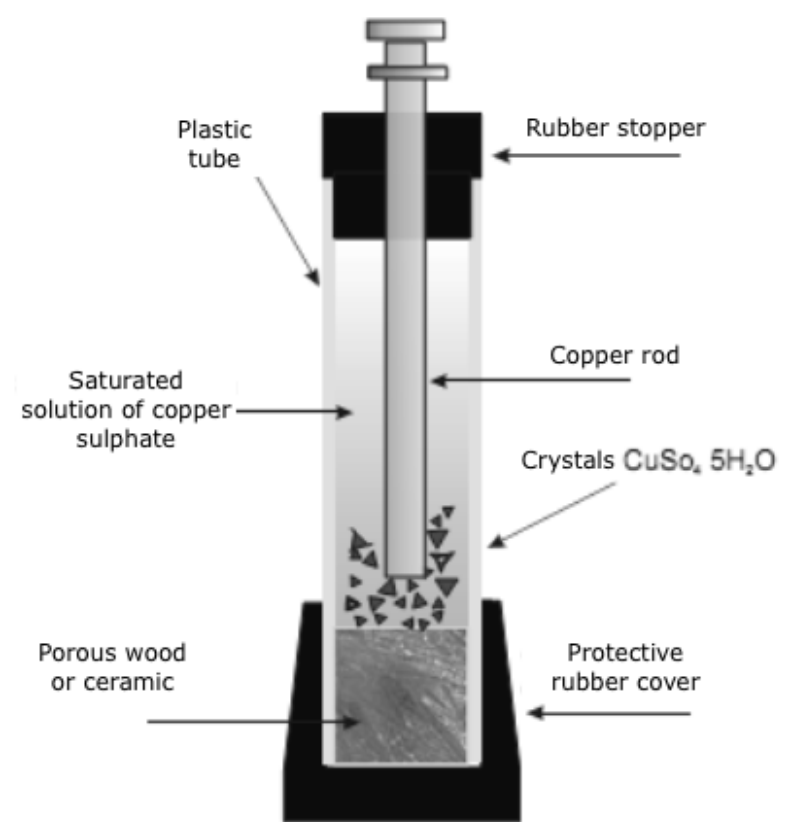

Fig. 2 Schematic of a reference electrode copper/saturated copper sulfate.

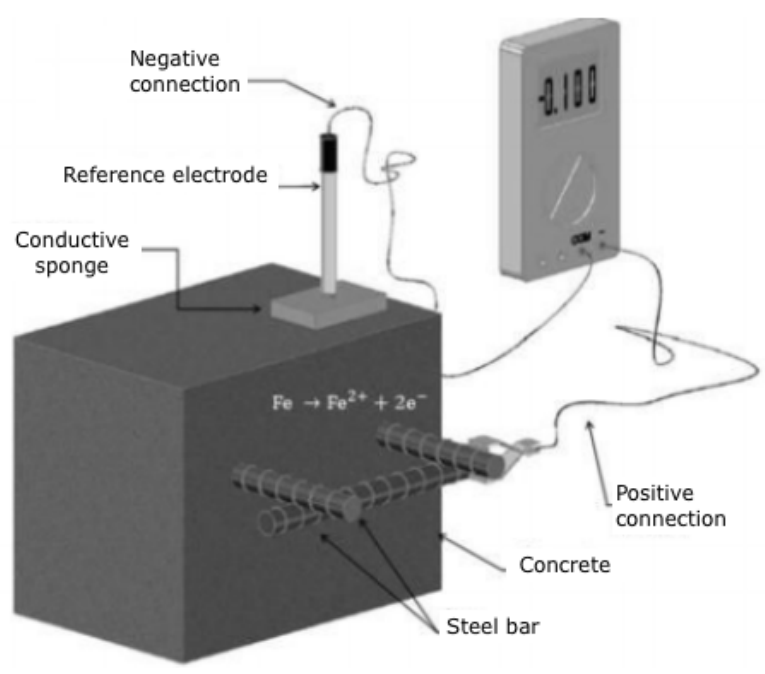

Fig. 3 Corrosion potential evaluation method.

The method consists in measuring the electrical potential difference between the steel bar of the reinforced concrete in analysis and a reference electrode, able to maintain its stable electrical potential. By connecting the reference electrode and the working electrode (reinforcement bar), a flow of electron from the rebar is generated toward the reference electrode, nobler and more positive potential, passing through the high impedance voltmeter and indicating the electrode potential difference between the half cells (reference electrode and working electrode). For circuit closing, a conductive interface is needed between the reference electrode and the working electrode. This is made by placing a saturated sponge in electrical contact between the reference electrode and the concrete surface (Fig. 3) [3].

As a criterion for evaluation of the corrosion phenomenon, ASTM C-876 [8] presents a correlation between intervals of potential and the probability of the occurrence thereof, as shown in Table 2 [5].

Finally, it should be considered that all tests were initially calibrated in the laboratory. The purpose of this adjustment is to obtain reliable results in controlled situations and environments so that it could be done a comparison with those obtained in the field.

\section{Case Study}

The cases of studies are two bridges on BR-277 highway, located in Curitiba, where there is intense traffic of heavy loaded vehicles. Named in the files in DNIT engineering projects like overpasses Stake 640, the nature of transposition is the passage over Ciro Pereira Street. According to the consulted registrations, the bridges were built in 1977 , thus having 38 years. During their life cycle, they underwent maintenance works. They have a length of $50.0 \mathrm{~m}$ and the total width of $12.5 \mathrm{~m}$, two tracks with one-way traffic each. The structural system is prestressed concrete system, shaped on site and exposed in a Class II urban areas [9], according to NBR 6118:2014. According to calculation memorial found, a Class 36 [10], a Class 36 vehicle type (corresponding to a $360 \mathrm{kN}$ weight) [10] was chosen for calculation, a common parameter at that time. Currently, the new standard NBR 7188 [11] would establish a Class 45 vehicle type, i.e., $450 \mathrm{kN}$. Figs. 4-5 make up the photographic record of inspections. The identification used by the DNIT and in this work to identify each of the bridges is 83.a and 83.b, according to Figs. 4-5. 
Table 2 Evaluation criteria of the results of potentials measurements in accordance with ASTM C 876.

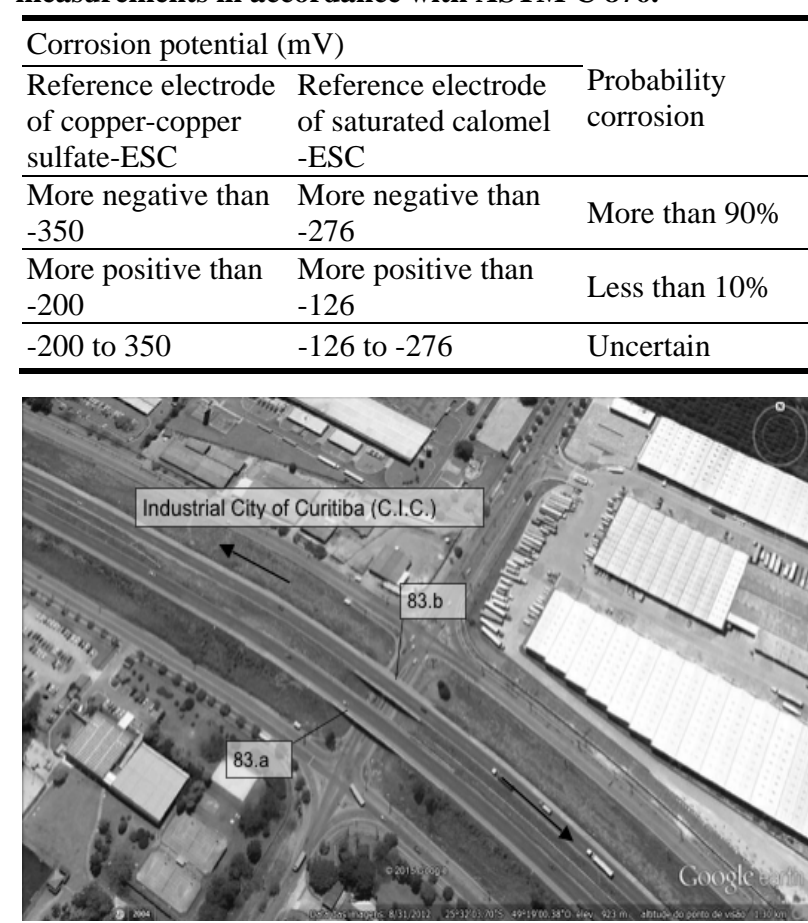

Fig. 4 Satellite image, identifying the works (Google Earth, 2015).

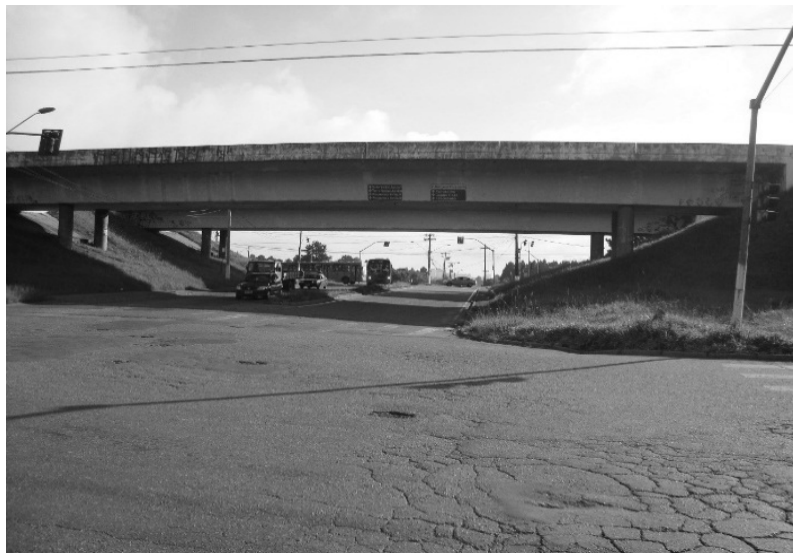

Fig. 5 General view of 83.a.

\section{Results}

\subsection{Testing the Prismatic Bars}

\subsubsection{Electrical Resistivity}

Table 3 shows the electrical resistivity results from the readings taken in prismatic bars of reinforced concrete in the laboratory.

\subsubsection{Corrosion Potential}

The results of the corrosion potential in the tests performed in laboratory with prismatic shaped bars are shown in Table 4.

\subsection{Tests Performed on Bridges}

Evaluation of the surface hardness of concrete was performed for the four bridge columns and are presented in Table 5.

As can be seen the bridge 83.a, Column P2 had the highest resistance value, while Column P1 had the lowest, and the difference between them of 5.1 MPa. The bridge 83.b's greatest resistance value was found in Column P4 and the lowest value in Column P2.

\subsubsection{Electrical Resistivity}

It can be observed in Table 6 that only Column P3 has low/moderate corrosion risk while others studied columns have low risk of corrosion.

Column P3 on viaduct 83.b has the worst result of electrical resistivity, therefore, with higher conductivity. It is worth mentioning that Column P3 had mapped cracking caused by fire located at the foot of the column. Therefore, this pathological manifestation may have interfered directly in the results, because it was located in the region where the readings took place. Cracks, besides allowing percolation of water and humidity easily into the structure, also facilitate the travel of electric current, as well as other spoilage agents.

Table 3 Results of the electrical resistivity testing of prismatic samples.

\begin{tabular}{llll}
\hline Element & Face & Result $(\mathrm{kohm} \cdot \mathrm{cm})$ & Risk of corrosion \\
\hline \multirow{4}{*}{ V1 } & F1 & 32.3 & \\
& F2 & 36.5 & \\
& F3 & 33.2 & Low \\
& F4 & 30.8 & \\
& Average & 33.2 & \\
& F1 & 9.1 & \\
V2 & F2 & 9.9 & \\
& F3 & 10.5 & \\
& F4 & 9.0 & \\
& Average & 9.6 & Low/moderate \\
& F1 & 8.5 & \\
V3 & F2 & 5.3 & \\
& F3 & 8.9 & \\
& F4 & 9.9 & \\
& Average & 8.2 &
\end{tabular}


Table 4 Potential results of corrosion of prismatic samples.

\begin{tabular}{|c|c|c|c|c|c|c|}
\hline \multirow{2}{*}{ Element } & \multirow{2}{*}{ Steel bar } & \multirow{2}{*}{ Coverings (cm) } & \multicolumn{3}{|c|}{ Corrosion potential $(\mathrm{m} \cdot \mathrm{V})$} & \multirow{2}{*}{ Probability corrosion } \\
\hline & & & $5 \mathrm{~cm}$ & $20 \mathrm{~cm}$ & $35 \mathrm{~cm}$ & \\
\hline \multirow{4}{*}{ V1 } & A1 & 3 & -34 & -22 & -32 & Less than $10 \%$ \\
\hline & $\mathrm{A} 2$ & 3 & - & - & - & - \\
\hline & A3 & 1 & -95 & -105 & -98 & Less than $10 \%$ \\
\hline & A4 & 1 & -120 & -115 & -125 & Less than $10 \%$ \\
\hline \multirow{4}{*}{ V2 } & A1 & 3 & -230 & -255 & -245 & Uncertain \\
\hline & A2 & 3 & -208 & -218 & -211 & Uncertain \\
\hline & A3 & 1 & -241 & -265 & -275 & Uncertain \\
\hline & A4 & 1 & -256 & -281 & -295 & Uncertain \\
\hline \multirow{4}{*}{ V3 } & A1 & 3 & -134 & -146 & -125 & Less than $10 \%$ \\
\hline & $\mathrm{A} 2$ & 3 & -133 & -130 & -132 & Less than $10 \%$ \\
\hline & A3 & 1 & -174 & -164 & -164 & Less than $10 \%$ \\
\hline & A4 & 1 & -116 & -146 & -140 & Less than $10 \%$ \\
\hline
\end{tabular}

Table 5 Rebound hammer testing—result of bridges 83.a and 83.b.

\begin{tabular}{lll}
\hline \multicolumn{3}{c}{ Bridges 83.a } \\
\hline Column & Resistance (MPa) & Standard deviation (MPa) \\
\hline P1 & 66.1 & 3.6 \\
P2 & 71.2 & 3.4 \\
P3 & 69.0 & 4.4 \\
P4 & 69.8 & 3.0 \\
\hline & & \\
\hline Column & Resistance (MPa) & Standard deviation (MPa) \\
\hline P1 & 70.1 & 1.9 \\
P2 & 68.1 & 1.8 \\
P3 & 71.0 & 1.7 \\
P4 & 71.6 & 1.9 \\
\hline
\end{tabular}

Table 6 Results of the electrical resistivity tests of viaducts 83.a and 83.b.

\begin{tabular}{lll}
\hline \multicolumn{3}{l}{ Bridges 83.a } \\
\hline Column & Electrical resistivity $(\mathrm{kohm} \cdot \mathrm{cm})$ & Risk of corrosion \\
\hline P2 & 67 & Low \\
P3 & 42 & Low \\
\hline & & \\
\hline Column & Blectrical resistivity $(\mathrm{kohm} \cdot \mathrm{cm})$ & Risk of corrosion \\
\hline P2 & 59 & Low \\
P3 & 16.3 & Low/moderate \\
\hline
\end{tabular}

Only Column P3 has low/moderate corrosion risk while others studied columns have low risk of corrosion.

\subsubsection{Potential Corrosion}

The test results obtained on the bridges 83.a and 83.b are shown in Table 7.

The results of the 83.b overpass corrosion potential showed that the reinforcement of columns are tested with results superior to $-200 \mathrm{mV}$. Therefore, likely to corrosion below $10 \%$, thus, these columns are safe for corrosion reinforcement, until now, since the flyover 83.b points showed a $90 \%$ likelihood of corrosion at the foot of the columns P2 and P3. 
Table 7 Corrosion potential test results in bridges 83.a and 83.b.

\begin{tabular}{llll}
\hline & & Bridges 83.a & \\
\hline Column & Height $(\mathrm{cm})$ & Corrosion potential $(\mathrm{mV})$ & Probability corrosion \\
\hline P2 & 0 & -80 & Less than $10 \%$ \\
& 50 & -15 & Less than $10 \%$ \\
\hline & 100 & -30 & Less than $10 \%$ \\
& 150 & -41 & Less than $10 \%$ \\
\hline P3 & 0 & -50 & Less than $10 \%$ \\
& 50 & -37 & Less than $10 \%$ \\
\hline Column & 100 & -55 & Less than $10 \%$ \\
\hline & 150 & -57 & Less than $10 \%$ \\
\hline P2 & Height $(\mathrm{cm})$ & Corrosion potential $(\mathrm{mV})$ & \\
& 0 & -500 & Probability corrosion \\
\hline & 50 & -115 & Higher than $90 \%$ \\
P3 & 100 & -200 & Less than $10 \%$ \\
& 150 & -50 & Uncertain \\
& 0 & -450 & Less than $10 \%$ \\
\hline
\end{tabular}

\section{Conclusions}

Throughout this paper, it was discussed complementary methods of testing to routine inspection of special artworks. Such tests aimed at greater qualification and detailing of structural and functional characteristics of bridges and bridges.

When a bridge is submitted to only visual evaluations, as in PRO-10, some of their pathological manifestations may go unnoticed by inspectors. Although professionals are trained, they are not always able to identify all the deteriorating situations since they are not visible on the surfaces of the structures.

The corrosion potential test revealed the occurrence of problems with internal concrete armor indicating whether there was likely to occur steel oxidation even before the structure has some apparent evidence on the surface.

The hammer concrete test allowed to relate the surface resistance and the compressive strength of the concrete, making it possible to check their quality and compliance with the design data, without being necessary to remove samples of the structure.

Electrical resistivity testing made it possible to evaluate the occurrence of corrosion process in bars, taking into account the opposition of the material to the electric current flow, thus providing another parameter, other than that provided by the corrosion potential to assessing oxidation of steel.

These tests brought a new variety of data and information that could be used in the assessment of structures studied.

In addition, the tests proposed by this study were simple to perform and they could be run on a relatively consistent time with the inspection period of a bridge.

This scenario of using tests to get a greater number of quantitative data of bridges follows a current standard engineering, which not only considers the structure as the main factor for evaluating the building, but also puts various variables in the equation of operation and durability.

\section{References}

[1] Sahuinco, M. H. C. 2011. “Uilização de Métodos não 
Destrutivos e Semi-destrutivos na Avaliação de Pontes de Concreto Armado.” M.Sc. dissertation. Univ. of São Paulo. SP. (in Portuguese)

[2] Departamento Nacional de Infraestrutura de Transportes. 2004. DNIT 010/2004 - PRO: Inspeções em Pontes e Viadutos. (in Portuguese)

[3] Rocha, F. C. 2012. "Leituras de Potencial de Corrosão em Estruturas de Concreto Armado: Influência da Relação Água/Cimento, da Temperatura, da Contaminação por Cloretos, da Espessura de Cobrimento e do teor de Umidade do Concreto.” M.Sc. dissertation. Federal University of Paraná, Curitiba, PR. (in Portuguese)

[4] Cascudo, O. 1997. O Controle da Corrosão de Armaduras em Concreto: Inspeção e Técnicas Eletroquímicas. Goiânia: UFG. (in Portuguese)

[5] Pereira, E. 2006. "Avaliação do Processo de Corrosão Acelerada para Diferentes Dosagens de Concreto e Espessuras de Cobrimento." In Proceedings of VII SEMENGO. Universidade Estadual do Oeste do Paraná. Cascavel. (in Portuguese)

[6] Associação Brasileira de Normas Técnicas. 2012. NBR 7548: Concreto Endurecido-Avaliação da Dureza Superficial pelo Esclerômetro de Reflexão-Método de
Ensaio. Rio de Janeiro: Associação Brasileira de Normas Técnicas. (in Portuguese)

[7] Silva, E. P. 2010. “Avaliação do Potencial de Corrosão de Concretos Estruturais Produzidos Segundo as Prescrições da NBR 6118, Submetido a Ensaio de Corrosão Acelerado.” M.Sc. dissertation, Federal University of Ceará, Fortaleza. (in Portuguese)

[8] ASTM C 876-09. 1991. Standard Test Method for Half-Cell Potentials of Uncoated Reinforcing Steel in Concrete.

[9] Associação Brasileira de Normas Técnicas. 2014. NBR 6118: Design of Concrete Structures-Procedure. Rio de Janeiro: Associação Brasileira de Normas Técnicas.

[10] Associação Brasileira de Normas Técnicas. 2000. NBR NM 6 Vulcanized Elastomer Profile Extruded for Sealing Concrete Structure Expansioned Joint-Physical Properties, Accelerated Extraction and Alkali Effect Determination. Rio de Janeiro: Associação Brasileira de Normas Técnicas.

[11] Associação Brasileira de Normas Técnicas. 2013. NBR 7188: Road and Pedestrian Live Load on Bridges, Viaducts, Footbridges and Other Structures. Rio de Janeiro: Associação Brasileira de Normas Técnicas. 